\title{
МИКРОВОЛНОВОЙ СИНТЕЗ СОПОЛИМЕРОВ НА ОСНОВЕ АКРИЛАМИДА И АЛЛИОКСИФЕНИЛЗАМЕЩЕННЫХ ПОРФИРИНОВ РАЗЛИЧНОЙ ФУНКЦИОНАЛЬНОСТИ
}

\begin{abstract}
Н. Л. Печникова, И. В. Шилов, А. В. Любимцев, Т. А. Агеева
НАДЕЖДА ЛЕОНИДОВНА ПЕЧНИКОВА - кандидат химических наук, научный сотрудник кафедры «Химия и технология высокомолекулярных соединений» ФГБОУ ВО «Ивановский государственный химикотехнологический университет». Область научных интересов: синтез порфиринов и порфиринсодержащзихполимеров.E-mail: peclin@mail.ru.
\end{abstract}

ИВАН ВАДИМОВИЧ ШИЛОВ - магистрант кафедры «Химия и технология высокомолекулярных соединений» ФГБОУ ВО «Ивановский государственный химико-технологический университет». Область научных интересов: синтез порфиринсодержащих полимеров. E-mail: schilovivan.2013@yandex.ru.

\begin{abstract}
АЛЕКСЕЙ ВАСИЛЬЕВИЧ ЛЮБИМЦЕВ - доктор химических наук, доиент кафедры «Химия и технология высокомолекулярных соединений» ФГБОУ ВО «Ивановский государственный химико-технологический университет». Область научных интересов: синтез и свойства природных и синтетических порфиринов и хлоринов.E-mail: alexlyubimtsev@mail.ru.
\end{abstract}

ТАТЬЯНА АРСЕНЬЕВНА АГЕЕВА - кандидат химических наук, доцент кафедры «Химия и технология высокомолекулярных соединений» ФГБОУ ВО «Ивановский государственный химико-технологический университет». Область научных интересов: синтез и исследование порфиринсодержащих полимеров и новых функциональных материаловна их основе. E-mail: tageeva@isuct.ru.

153000, Россия, Иваново, пр. Шереметевский, д. 7, Институт макрогетероциклических соединений Ивановского государственного химико-технологического университета.

В условиях микроволнового излучения и термического нагрева получены водорастворимые порфиринполимеры на основе акриламида и моно- и тетра-мезо-аллилоксифенил-замещенных порфиринов. Показано, что при одинаковом соотношении исходных компонентов содержание порфирина, имеющего на периферии молекулы четыре активные группы, в полимерной цепи выпе, чем порфирина с одной активной группой. При одинаковых загрузках исходных компонентов содержсание порфирина в полимерах, полученных в условиях МВИ, выше, чем содержание порфирина в полимерах, полученных в условиях термического нагрева.

Ключевые слова: микроволновой синтез, порфириновые мономеры, водорастворимые порфиринполимеры. 


\title{
MICROWAVE SYNTHESIS OF COPOLYMERS BASED ON ACRYLAMIDE AND ALLYLOXYPHENYL SUBSTITUTED PORPHIRINES OF DIFFERENT FUNCTIONALITY
}

\author{
N. L. Pechnikova, I. V. Shilov, A. V. Lyubimtsev, T.A. Ageeva \\ 7, Sheremetievskiy Avenue, Ivanovo, 153000, Russia. Ivanovo State University of Chemistry and Technology.
}

\begin{abstract}
The water-soluble porphyrin-polymers based on acrylamide and mono- and tetra-meso-allyloxyphenyl-substituted porphyrins under microwave irradiation and thermal heating were obtained. It was shown that the content of the porphyrin, having four active groups on the periphery of the molecule, is higher in the polymer chain than the porphyrin content with one active group, with the same ratio of the initial components. The porphyrin content in polymers prepared under microwave conditions is higher than the porphyrin content in polymers synthesized under thermal heating with identical weights of the starting compounds.
\end{abstract}

Key words: microwave synthesis, porphyrin monomers, water-soluble porphyrin-polymers.

\section{Введение}

Синтез гибридных полимерных соединений, содержащих в своем составе порфирины и их родственные соединения, позволяет получать уникальные на их основе материалы, обладающими фотокаталитическими, антимикробными, сенсорными и другими полезными свойствами [1-6]. В последние годы для получения таких соединений активно используется микроволновое излучение (МВИ), которое вносит заметный вклад в методологию синтеза различных органических соединений, в том числе полимеров [7-12] и тетрапиррольных макрогетероциклических соединений [13-16]. Применение МВИ позволяет не только в разы сократить время реакции, но и увеличить выход синтезируемых соединений. Во многих случаях в условиях микроволнового излучения удается получить продукты реакции, которые в условиях термического нагрева не образуются или получаются с малыми выходами, что открывает большие возможности использования МВИ для синтеза различных функциональных материалов.

В работе были получены водорастворимые порфиринполимеры на основе акриламида (АА) и моно- и тетра-мезо-аллилоксифенил-замещенных порфиринов в условиях МВИ и термического нагрева. Описаны спектральные особенности водных растворов синтезированных порфиринполимеров, выявлены особенности проведения процесса сополимерзации АА с порфириновыми мономерами в различных условиях.

\section{Экспериментальная часть}

$$
\text { Приборы и материаль }
$$

Экспериментальные данные получены с использованием ресурсов Центра коллективного пользования научным оборудованием ФГБОУ ВО «ИГХТУ».

Для синтеза водорастворимых порфиринполимеров использовали коммерческий акриламид, который очищали перекристаллизацией из хлороформа дважды [17]. В качестве инициатора радикальной сополимеризации применяли динитрил азобисизомасляную кислоту (ДАК), который очищали перекристаллизацией из этилового спирта дважды [17].

Синтез порфиринполимеров в условиях МВИ проводили с помощью микроволновой системы Discover (CEM Corporation) с частотой магнетрона 2455 МГц в динамическом режиме с заданной мощностью 30 Вт.

Электронные спектры поглощения (ЭСП) водных растворов сополимеров регистрировали на спектрофотометре SHUMADZU UV-2550 с воспроизводимостью 0,05 нм. Все измерения проводились в стандартных кварцевых кюветах толщиной 0,2 и 1 см при комнатной температуре. Область измерений составила 300-800 нм. Титр водных растворов сополимеров -2 мг/мл.

Морфологию поверхности полученных порфиринполимеров исследовали с помощью сканирующего электронного микроскопа Tescan Vega 3 
(Чехия), источником электронов в котором является вольфрамовый катод с термоэмиссией. Образцы, закрепленные на латунных держателях и предварительно покрытые углеродом с использованием установки для напыления токопроводящих покрытий (Q150TES, Quorum Technologies, Великобритания), были сканированы в режиме высокого вакуума при разрешении 5-20 $\mu$ м с ускоряющим напряжением 5-10 кВ.

\section{Микроволновой синтез порфиринполимеров}

Акриламид и соответствующий порфириновый мономер (P1, P2) (массовое соотношение исходных реагентов приведено в табл. 1) растворяли в 4 мл 1,4-диоксана, добавляли 1 мг ДАК, зачем продували в течение 15 минут азотом и помещали в лабораторную микроволновую систему Discover. Синтез проводили при постоянном перемешивании в течение 50 минут при $70{ }^{\circ} \mathrm{C}$. По окончании реакции образовавшийся осадок сополимера отфильтровывали, промывали хлороформом и высушивали при $50{ }^{\circ} \mathrm{C}$. Выход сополимеров и рецептура загрузки исходных компонентов представлены в табл. 1.

Таблица 1

Рецептура загрузки и выход сополимеров в условиях МВИ

\begin{tabular}{ccc}
\hline $\begin{array}{c}\text { Сополимер } \\
\text { АА-P }\end{array}$ & $\begin{array}{c}\text { Массовое соотношение } \\
\text { P:AA }\end{array}$ & $\begin{array}{c}\text { Выход, } \\
\text { \% }\end{array}$ \\
\hline $\mathbf{1 . 1}$ & $1: 20$ & 90,25 \\
$\mathbf{1 . 2}$ & $1: 10$ & 94,55 \\
$\mathbf{1 . 3}$ & $3: 20$ & 94,50 \\
$\mathbf{2 . 1}$ & $1: 20$ & 94,45 \\
$\mathbf{2 . 2}$ & $1: 10$ & 95,20 \\
$\mathbf{2 . 3}$ & $3: 20$ & 95,00 \\
\hline
\end{tabular}

\section{Синтез порфиринполимеров в условиях термического нагрева}

Акриламид и соответствующий порфириновый мономер (P1, P2) (массовое соотношение реагентов приведено в табл. 2) растворяли в 4 мл 1,4-диоксана, добавляли 1 мг ДАК, зачем продували в течение 15 минут азотом и помещали в масляную баню. Синтез проводили при $70{ }^{\circ} \mathrm{C}$ в течение 4 часов при постоянном перемешивании. По окончании реакции выпавший осадок сополимера отфильтровывали, промывали хлороформом и высушивали до постоянной массы при $50{ }^{\circ} \mathrm{C}$. Выход сополимеров и рецептура загрузки исходных компонентов указаны в табл. 2.
Таблииа 2

Рецептура загрузки и выход сополимеров в условиях термического нагрева

\begin{tabular}{ccc}
\hline $\begin{array}{c}\text { Сополимер } \\
\text { AA-P }\end{array}$ & $\begin{array}{c}\text { Массовое соотношение } \\
\text { P:AA }\end{array}$ & $\begin{array}{c}\text { Выход, } \\
\text { \% }\end{array}$ \\
\hline $\mathbf{1 . 1}$ & $1: 20$ & 95,75 \\
$\mathbf{1 . 2}$ & $1: 10$ & 98,90 \\
$\mathbf{1 . 3}$ & $3: 20$ & 99,50 \\
$\mathbf{2 . 1}$ & $1: 20$ & 98,40 \\
$\mathbf{2 . 2}$ & $1: 10$ & 99,45 \\
$\mathbf{2 . 3}$ & $3: 20$ & 97,60 \\
\hline
\end{tabular}

\section{Результаты и их обсуждение}

Для синтеза водорастворимых полимеров использовали такие порфириновые мономеры как 5,10,15,20-тетракис-(5-(4'-аллилокси)-фенил)порфирин (P1) и 5-(4'-аллилокси)-фенил)-10,15,20трифенилпорфирин (P2), структурные формулы которых представлены на рис. 1. Порфириновые мономеры (P1) и (P2) были синтезированы модификацией соответствующих тетра- и моно-мезогидроксифенил-замещенных порфиринов по методикам $[18,19]$. Далее проводили алкилирование полученных тетра- и моно- мезо-гидроксифенилпорфиринов бромистым аллилом до соответствующих аллилоксифенил-замещенных производных $[20,21]$. Структуру синтезированных соединений подтверждали методами ЯМР-спектроскопии и масс-спектрометрии.

Порфириновые мономеры отличаются количеством винильных групп на периферии макрогетероцикла, которые участвуют в реакции сополимеризации с акриламидом. Количество функциональных групп в молекуле изменяет активность порфириновых мономеров, что теоретически позволяет получить не только линейные порфиринполимеры, но также и сшитые структуры.

Реакцию радикальной сополимеризации АA с 5,10,15,20-тетракис-(5-(4'-аллилокси)-фенил)порфирином (P1) и 5-(4'-аллилокси)-фенил)10,15,20-трифенилпорфирином (Р2) проводили в 1,4-диоксане. В качестве инициатора сополимеризации использовали ДАК. В результате были получены порфиринсодержащие полимеры (1.1'2.3') в условиях МВИ и порфиринсодержащие полимеры (1.1-2.3) в условиях термического нагрева.

Схема реакции АА с порфирином (P1) приведена на рис. 2.

На начальном этапе были выбраны оптимальные условия синтеза порфиринполимеров. Наиболее подходящим растворителем для проведения процесса сополимеризации является 1,4-ди- 


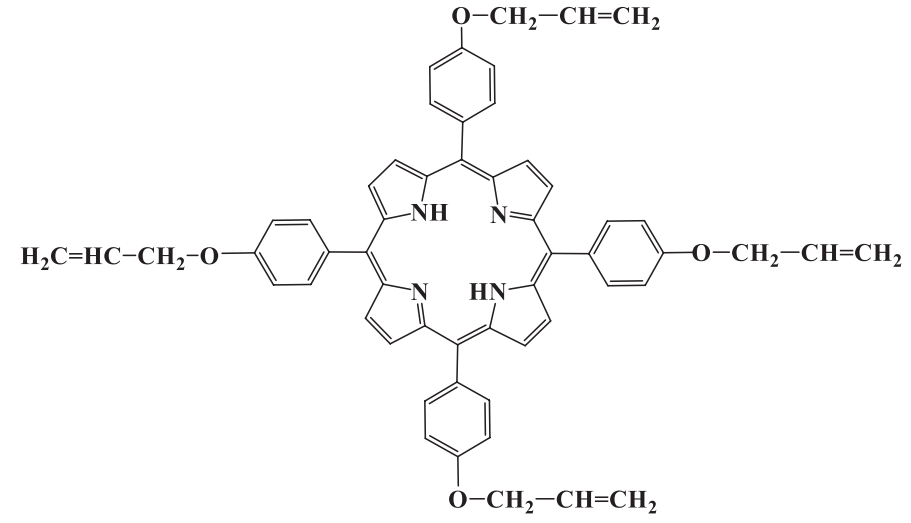

P1

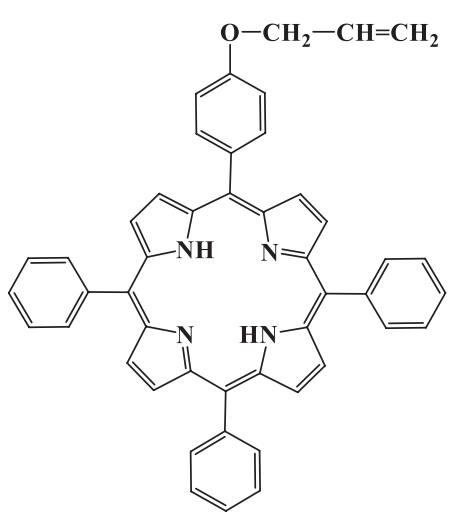

P2

Рис. 1. Структурные формулы порфириновых мономеров (P1) и (Р2)

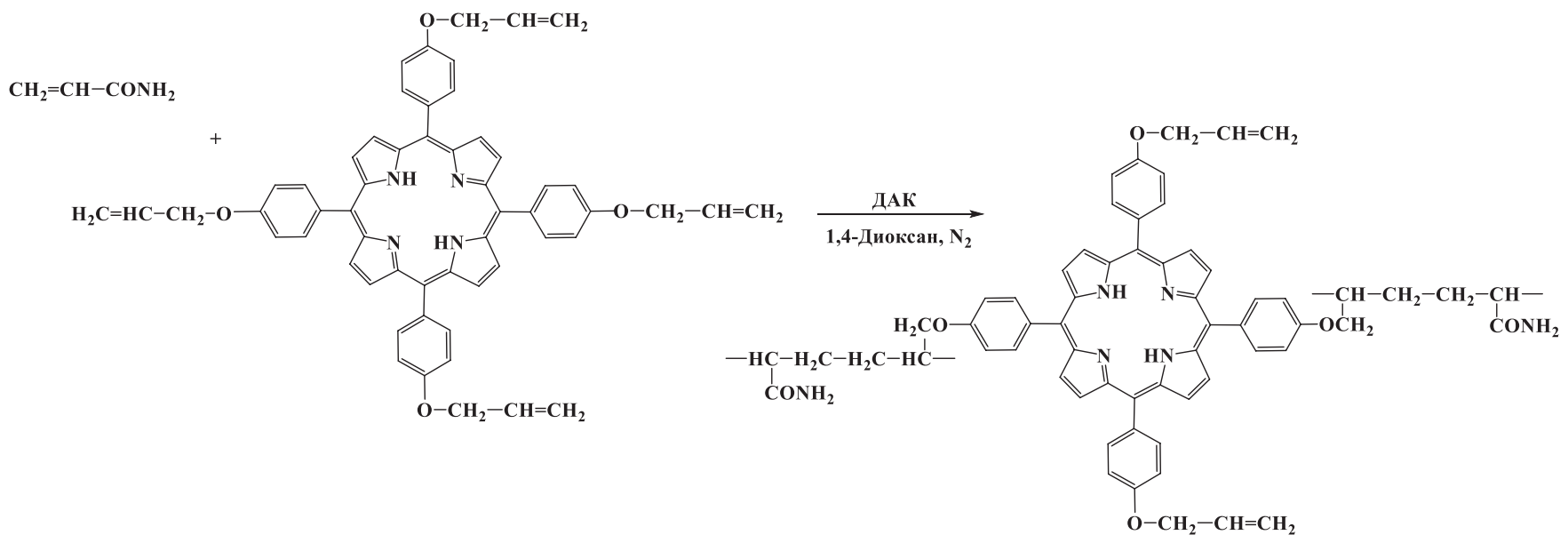

Рис. 2. Схема реакции акриламида с 5,10,15,20-тетракис-(5-(4'-аллилокси)-фенил)-порфирином

оксан, так как он обеспечивает необходимую растворимость всех компонентов реакции и не является активным передатчиком цепи. Синтез порфиринполимеров в условиях термического нагрева при 1 \%-ом содержании инициатора от массы полимера протекает только в среде инертного газа. В противном случае не образуется ни гомополимер, ни сополимер. Было показано, что в присутствии кислорода воздуха увеличение содержания инициатора в реакционной массе до 2 масс.\% позволяет увеличить выход продуктов реакции за 8 часов процесса до $5 \%$ и до $30 \%$ за 12 часов процесса. Однако в этих условиях не удается достигнуть воспроизводимости результатов эксперимента. Проведение реакции сополимеризации в условиях термического нагрева в инертной среде позволило получить порфиринполимеры различного состава с хорошими выходами 95,75-99,50 \%. В условиях МВИ порфиринполимеры образуются как в инертной среде, так и в присутствии кислорода воздуха. Однако, чтобы исключить образо- вание пероксидов и предотвратить окислительную деструкцию уже полученных порфиринполимеров все синтезы проводились в атмосфере азота.

Все полученные порфиринполимеры окрашены от светло-розового до кирпичного цвета. Интенсивность окраски возрастает по мере увеличения содержания порфирина в полимере. Синтезированные сополимеры хорошо растворимы в водных растворах, однако при увеличении содержания порфирина в порфиринполимере выше 15 мг их растворимость снижается.

Выход всех сополимеров при увеличении содержания порфирина в исходной смеси практически не уменьшается как в случае МВИ, так и в случае термического нагрева (Табл. 1 и 2).

Молекулярные массы всех синтезированных сополимеров были определены вискозиметрическим методом [17] (Табл. 3).

Молекулярные массы порфиринполимеров, полученных в условиях микроволнового излучения, в 1,5-2 раза меньше, чем молекулярные массы 


\begin{tabular}{|c|c|c|c|}
\hline \multicolumn{4}{|c|}{ Молекулярные массы полученных сополимеров } \\
\hline $\begin{array}{c}\text { Сополимер } \\
\text { AA-P1 }\end{array}$ & MM & $\begin{array}{c}\text { Сополимер } \\
\text { АA-P2 }\end{array}$ & MM \\
\hline 1.1 & 39300 & 2.1 & 38000 \\
\hline 1.2 & 62300 & 2.2 & 43500 \\
\hline 1.3 & 27700 & 2.3 & 52700 \\
\hline $1.1^{\prime}$ & 21400 & 2.1 & 17600 \\
\hline $1.2^{\prime}$ & 38800 & 2.2 & 28900 \\
\hline $1.3^{\prime}$ & 12900 & $2.3^{\prime}$ & 28000 \\
\hline
\end{tabular}

порфиринполимеров, полученных в условиях термического нагрева. Очевидно, что в условиях микроволнового излучения обрыв цепи происходит интенсивнее, что в свою очередь и приводит к уменьшению молекулярной массы образующихся порфиринполимеров. Под действием микроволнового излучения распад инициатора на свободные радикалы происходит быстрее, чем в обычных условиях, что, в свою очередь, ведёт к образованию большего количества центров реакции, а это оказывает влияние на дальнейший рост цепи образующегося сополимера.

Все синтезированные сополимеры были исследованы спектрофотометрическим методом. На рис. 3 приведены ЭСП растворов сополимеров на основе АА и порфирина (P1), полученных в различных условиях. Сравнение интенсивностей полос поглощения растворов сополимеров показывает, что чем больше содержание порфирина при загрузке исходных компонентов, тем выше его содержание в образующемся порфиринполимере. Полученные данные показывают, что содержание порфирина в порфиринполимерах, полученных в условиях МВИ, выше, чем содержание порфирина в порфиринполимерах, полученных в условиях термического нагрева. При этом как в условиях термического нагрева, так и в условиях МВИ увеличение массы порфирина при загрузке исходных компонентов в два раза с 5 до 10 мг не приводит к существенному увеличению содержания порфирина в соответствующем порфиринполимере. Об этом свидетельствует незначительное увеличение интенсивностей полос в ЭСП водных растворов сополимеров $(\mathbf{1 . 1}, \mathbf{1 . 2})$ и (1.1', 1.2'). Только при трехкратном увеличении количества порфирина при загрузке исходных реагентов происходит существенное увеличение интенсивности полос поглощения растворов сополимеров в ЭСП, а, следовательно, и содержания порфиринового мономера в сополимере.

Характер изменения интенсивностей полос поглощения водных растворов сополимеров (2.1-2.3), (2.1'-2.3') на основе АА и моно-замещенного пор-

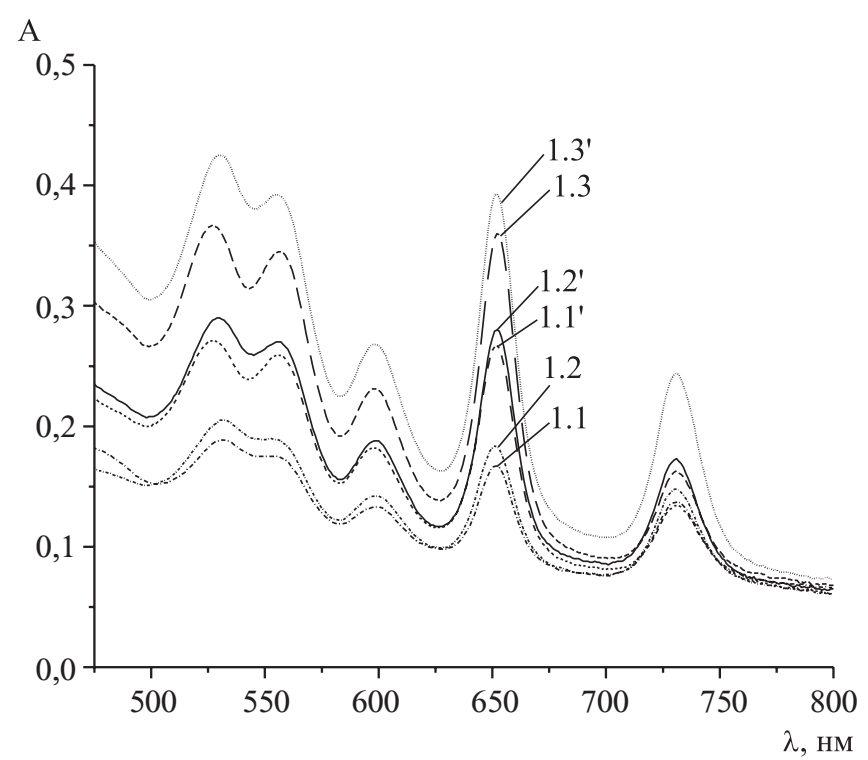

Рис. 3. ЭСП водных растворов сополимеров, полученных в термических условиях $(1.1-1.3)$ и в условиях МВИ (1.1' - 1.3')

фирина (P2) отличен от сополимеров, содержащих тетра-замещенный порфирин (Рис. 4). В первом случае в ЭСП растворов порфиринполимеров, полученных в условиях МВИ (2.1'-2.3'), наблюдается равномерное увеличение интенсивностей полос поглощения в ЭСП, а, следовательно, и содержания порфирина в сополимерах. Тогда как в случае порфиринполимеров, синтезированных в термических условиях (2.1-2.3), заметное увеличение содержания порфирина в порфиринполимере наблюдается при переходе от соотношения Р:AA=1:20 до P:AA=1:10. Дальнейшее увеличение концентрации порфирина в исходной смеси приводит лишь к незначительному увеличению интенсивностей полос поглощения в ЭСП.

ЭСП водных растворов порфиринполимеров, полученных с использованием порфириновых мономеров, имеющих разное количество винильных групп на периферии макромолекулы, приведены на рис. 5.

Из полученных данных следует, что у сополимеров, полученных при одинаковом соотношении исходных компонентов, но с различными порфириновыми мономерами, содержание тетра-замещенного порфиринового мономера (P1) в сополимерах выше, чем содержание моно-замещенного порфиринового мономера (Р2).

Нами были замечены отличительные особенности спектров поглощения исходных порфириновых мономеров и порфиринполимеров на их основе (Рис. 6). В длинноволновой области спектров поглощения водных растворов всех сополимеров появляется дополнительная полоса погло- 

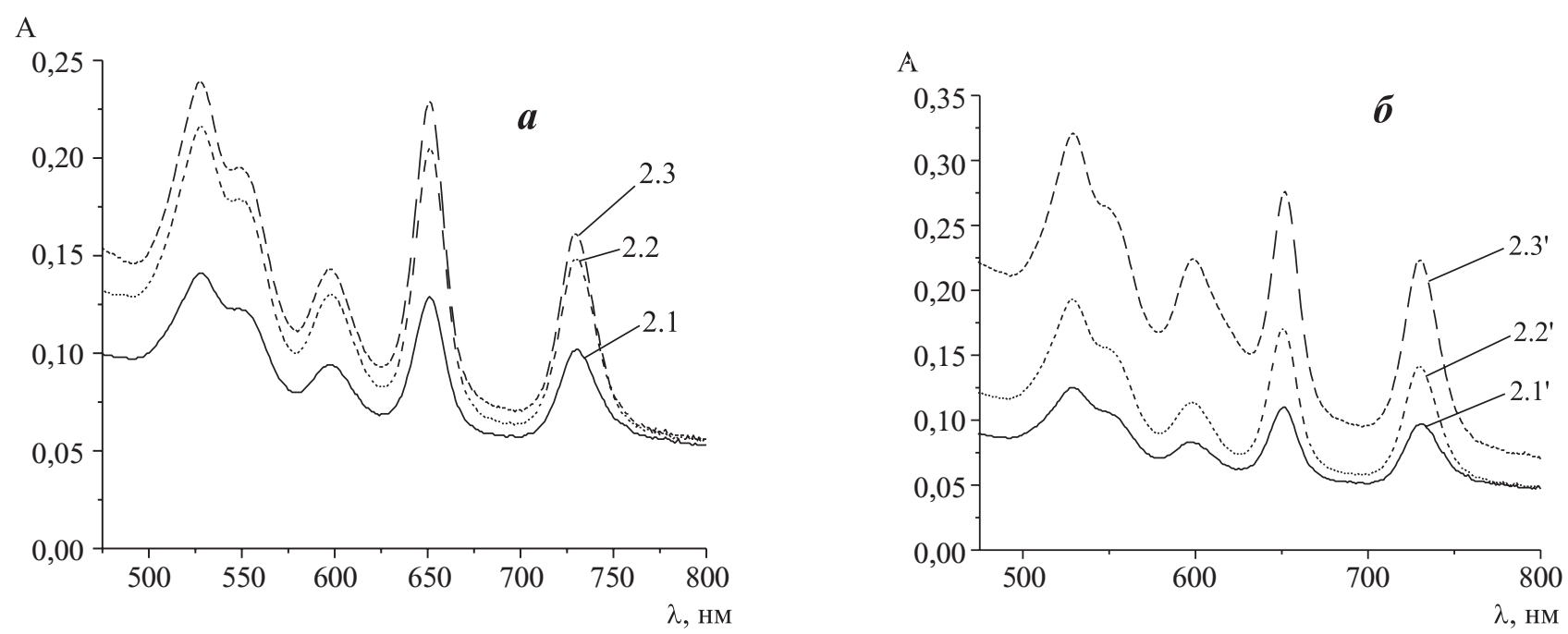

Рис. 4. ЭСП водных растворов сополимеров АА с 5-(4'-аллилокси)-фенил)-10,15,20-трифенилпорфирином (2.1-2.3) и (2.1'-2.3'):

$\boldsymbol{a}$ - полученных в термических условиях; б - в условиях МВИ
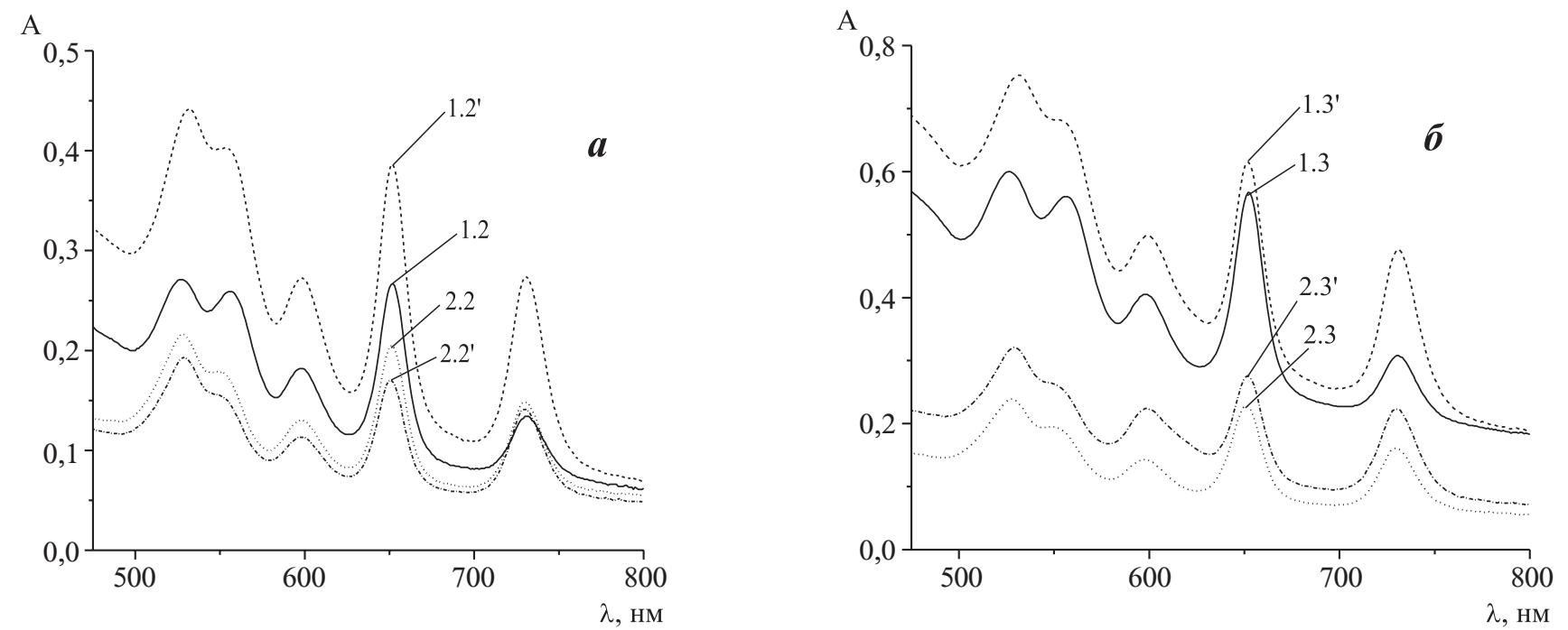

Рис. 5. ЭСП сополимеров АА с 5,10,15,20-тетракис-(5-(4'-аллилокси)-фенил)-порфирином и 5-(4'-аллилокси)-фенил)-10,15,20-трифенилпорфирином:

$\boldsymbol{a}$ - полученные при соотношении $P: A A=1: 10 ; \boldsymbol{\sigma}$ - полученные при соотношении $P: A A=3: 20$

щения при 730 нм, интенсивность которой возрастает при увеличении содержания порфирина в исходной смеси. Для установления причины такого различия была проведена реакция взаимодействия порфириновых мономеров с используемым инициатором без акриламида в условиях МВИ и термического нагрева. Характер полос поглощения взаимодействия компонентов по истечении времени не изменился. Предположительно, на изменение характера полос поглощения синтезированных порфиринполимеров существенное влияние оказывает полимерная матрица, и по мере протекания реакции радикальной сополимеризации происхо- дит не только встраивание порфириновых звеньев в растущую макромолекулярную цепь, но и изменение структуры порфириновых мономеров. Предположительно, помимо звеньев порфириновых мономеров в порфиринополимере присутствуют звенья бактериохлоринов, характерной особенностью которых является появление в длинноволновой области интенсивной полосы поглощения в области 735 нм [22-26].

Ранее в работе [27] было показано, что при проведении процесса сополимеризации метилметакрилата с порфиринами, содержащими одну винильную группу на периферии макроцикла, в термических 


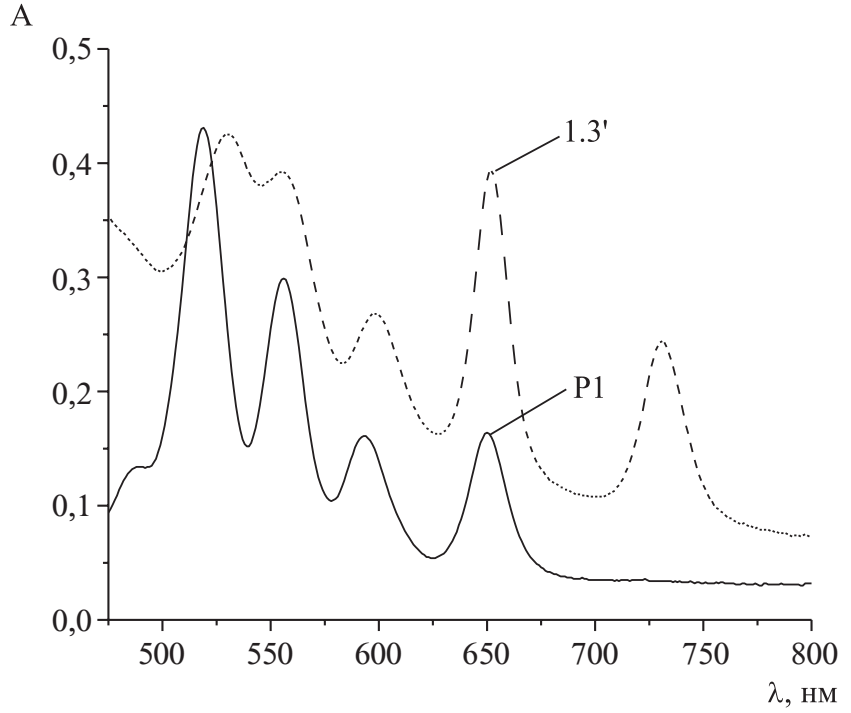

Рис. 6. ЭСП водного раствора синтезированного сополимера (1.3') и исходного порфиринового мономера (P1) в хлороформе

\section{Выводы}

Таким образом, было показано, что использование порфириновых мономеров, содержащих разное количество винильных групп на периферии макроцикла и отличающихся функциональностью в реакции радикальной сополимеризации с акриламидом, позволяет синтезировать различные по составу водорастворимые порфиринполимеры. Наибольшее содержание порфирина в полимерной цепи достигается при использовании тетра-замещенного порфирина в качестве сомономера в реакции сополимеризации с АА в условиях МВИ. Во всех синтезированных порфиринполимерах помимо звеньев порфириновых мономеров содержатся бактериохлориновые фрагменты, однако данное предположение требует дополнительных методов исследования, что позволит целенаправленно получать порфиринполимеры с заданным содержанием определенных тетрапиррольных макрогетероциклов.

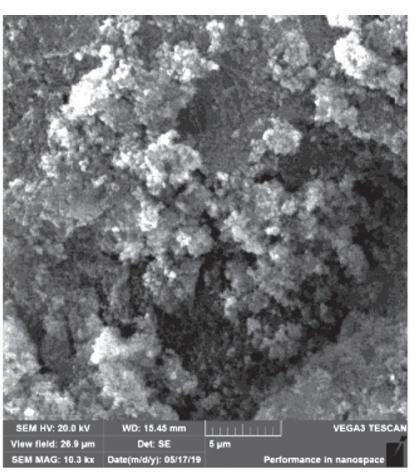

a

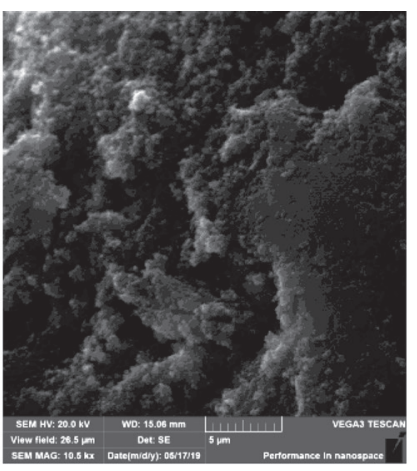

б

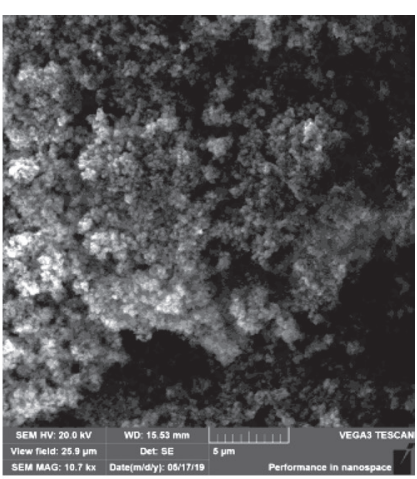

B

Рис. 7. Морфология поверхности сополимеров 2.2' (a), 1.3 (б) и ПАА (в)

условиях также наблюдалось изменение характера полос поглощения синтезированных сополимеров по сравнению с ЭСП растворов исходных порфиринов. В длинноволновой области при 650 нм появлялась дополнительная полоса поглощения характерная для хлориновых структур [22-26, 28].

Морфологию поверхности полученных порфиринполимеров исследовали с помощью сканирующего электронного микроскопа Tescan Vega 3. На рис. 7 представлены микрофотографии поверхности полученных порфиринполимеров, а также полиакриламида (ПАА).

Из полученных данных следует, что все образцы имеют достаточно рыхлую структуру, и включение порфирина в полимерную матрицу не меняет морфологию поверхности синтезированных порфиринполимеров в сравнении с ПАА без добавок.
Работа выполнена при финансовой поддержке гранта РФФИ (проект № 18-03-00986).

\section{Лuтература}

1. Feese E., Sadeghifar H., Gracz H.S., Argyropoulos D.S., Ghiladi R.A. Biomacromolecules. 2011. V. 12. № 10. P. 3528-3539.

2. Ringot C., Sol V., Granet R., Krausz P. Mater. Lett. 2009. V. 63. № 21. P. 1889-1891.

3. Zhu J., Sun G. J. Mater. Chem. 2012. V. 22. №21. P. 10581-10588.

4. Wang L., Qiao Z., Gao C., Liu J., Zhang Z.-G., Li X., Li Y., Wang H. Macromolecules. 2016. V. 49. № 10. P. 3723-3732.

5. Espinisa M., Pacheco S., Rodriguez R. J. Non-Cryst. Solids. 2007. V. 353. № 26. P. 2573-2581. 
6. Brulè E., de Miguel Y. Tetrahedron Lett. 2002. V. 43. № 47. P. 8555-8558.

7. Пономаренко А.Т., Тамеев А.Р., Шевченко В.Г. Russ. Chem. Rev. 2018. T. 87. № 10. P. 923-949.

8. Румянцева Ю.В., Кузнецчов Р.Е., Мудров А.Н., Агеева Т.А., Койфман О.И. Известия высших учебных заведений. Химия и химическая технология. 2012. Т. 55. № 12. C.114-116.

9. Monterde C., Navarro R., Iglesias M., Sánchez F. Appl. Mater. Interfaces. 2019. V. 11. №3. P. 3459-3465.

10. Bogdal D., Gorczyk J., Kwasek B. Sustainable Chem. Eng. 2016. V.4. № 6. P. 3024-3031.

11. Chanda K., Kuo J., Chen C.-H., Sun C.-M. J. Comb. Chem. 2009. V. 11. №2. P. 252-260.

12. Dalvi P.B., Lin S.-F., Paike V., Sun C.-M. Comb. Sci. 2015. V. 17. № 7. P. 421-425.

13. Dogutan D.K., Lindsey J.S. J. Org. Chem. 2008. V. 73. № 17. P. 6728-6742.

14. Dogutan D.K., Bediako D.K, Teets T.S., Schwalbe M., Nocera D.G. Org. Lett. 2010. V. 12. № 5. P. 1036-1039.

15. Jin H.-G., Jiang X., Kühne I.A., Clair S., Monnier V., Chendo C., Novitchi G., Powell A.K., Kadish K.M., Balaban T.S. Inorg. Chem. 2017. V. 56. № 9. P. 4864-4873.

16. Samaroo D., Soll C.E., Todaro L.J., Drain C.M. Org. Lett. 2006.V. 8. № 22. P. 4985-4988.

17. Торопиева А.М., Белогородская А.В., Бондаренко B.M. Лабораторный практикум по химии и технологии высокомолекуляных соединений. - Л.: Химия, $1972.416 \mathrm{c}$.

18. Любимова Т.В., Глазунов А.В., Сырбу С.А., Семейкин А.С., Быкова В.В., Жарникова Н.В., Ананьева Г.А.,
Усольцева Н.В. Жидкие кристаллы и их практическое использование. 2010. Т. 31. № 1. С. 23-36.

19. Salnikova M.A., Lubimova T.V., Glazynov A.V., Syrbu S.A., Semeikin A.S., Koifman O.I. Macroheterocycles. 2013. V. 6. № 1. Р. 53-58.

20. Семейкин А.С., Койфман О.И., Никитина Г.Е., Березин Б.Д. Журн. орг. химии. 1984. Т. 54. № 7. С. 15991603.

21. Sinha A.K., Bihari B., Mandal B. K. Macromolecules. 1995. V. 28. № 16. P. 5681-5683.

22. Bonnet R., Charlesworth P., Djelal B.D., Foley S., McGarvey D.J., Truscott T.G. J. Chem. Soc., Perkin Trans. 2. 1999. № 2. P. 325-328.

23. Bonnett R. and Martı'nez G. Org. Lett. 2002. V. 4. № 12. P. 2013-2016.

24. Stromberg J.R., Marton A., Kee H.L., Kirmaier C., Diers J.R., Muthiah C., Taniguchi M., Lindsey J.S., Bocian D.F., Meyer G.J., and Holten D. J. Phys. Chem. C. 2007. V. 111. № 42. P. 15464-15478.

25. Yang E., Wang J., Diers J.R., Niedzwiedzki D.M., Kirmaier C., Bocian D.F., Lindsey J.S., and Holten D. J. Phys. Chem. B. 2014. V. 118. №6. P. 1630-1647.

26. Wang J., Yang E., Diers J.R., Niedzwiedzki D.M., Kirmaier C., Bocian D.F., Lindsey J.S., and Holten D. J. Phys. Chem. B. 2013. V. 117. №31. P. 92889304.

27. Печникова Н.Л., Агеева Т.А., Сырбу С.А. Рос. хим. ж. 2015. T. 5. №№ 5-6. C. 69-73.

28. Greco J.A., Shima S., Wagner N.L., McCarthy J.R., Atticks K., Brückner C., and Birge R.R. J. Phys. Chem. C. 2015. V. 119. № 7. P. 3711-3724. 